\section{Identification of Resistance to Acidovorax avenae subsp. citrulli among Melon (Cucumis spp.) Plant Introductions}

\author{
W. Patrick Wechter' ${ }^{1}$, Amnon Levi, Kai-Shu Ling, \\ and Chandrasekar Kousik \\ U.S. Vegetable Laboratory, USDA, ARS, 2700 Savannah Highway, Charleston, \\ SC 29414
}

\author{
Charles C. Block \\ USDA, ARS, North Central Regional Plant Introduction Station (NCRPIS), \\ Plant Introduction Unit, Iowa State University, Ames, IA 50011
}

Additional index words. bacterial fruit blotch, cantaloupe, muskmelon, melon, cucurbit

\begin{abstract}
Bacterial fruit blotch (BFB) caused by the bacterium Acidovorax avenae subsp. citrulli (Aac) is a seed-borne disease that threatens most cucurbit crops. Although limited resistance has been found in a small number of Plant introductions (PIs) in watermelon (Citrullus spp.), there are no reports of high levels of resistance in germplasm lines of Cucumis spp. In this study, 332 Cucumis spp. PIs were screened for resistance to Aac using a newly developed seed vacuum-infusion assay. Significant differences in the reaction of the $P I$ to $B F B$ were observed. The majority of lines were found to be extremely susceptible to the disease. However, several PIs with lower levels of resistance were also identified. Variability in the reaction of plants within each PI was also observed. Of the 332 PI tested, 16 were selected for additional evaluation using a standard spray inoculation tests. PI 353814, PI 381171, PI 536573, and PI 614401, all belonging to C. melo, and PI 504558 (C. ficifolius) were found to have significantly greater levels of resistance than susceptible control cultivars or other PIs in two independent spray inoculation tests. Germplasm lines developed from these PIs may be useful as sources of resistance to BFB in Cucumis breeding programs.
\end{abstract}

Cucurbit crops are an extremely important agricultural commodity in the United States as well as worldwide. The two most important cucurbit crops in terms of overall production in the United States are watermelon (Citrullus lanatus var. lanatus) and muskmelon (also called cantaloupe or melon) (Cucumis melo). Records show that nearly two billion pounds of muskmelons were produced in the United States in 2008 with a market value of $\$ 371$ million (USDA, NASS, 2009). Pest and disease pressures, including bacterial, fungal, and nematode pathogens, are quite high on these two cucurbit crops (Zitter et al., 1996). Although a number of pesticides are available to control some of these pathogens, little is

Received for publication 28 Sept. 2010. Accepted for publication 28 Oct. 2010.

We acknowledge the excellent technical assistance of Ellis Caniglia, M.K. Ruddy, Kathy Reitsma, and Casey Conrad with this project. We also thank Dr. Ron Walcott for the bacterial isolates used in this study.

The contents of this publication do not necessarily reflect the views or policies of the USDA nor does the mention of trade names, commercial products, or organizations imply endorsement by the U.S. Government.

${ }^{1}$ To whom reprint requests should be addressed; e-mail Pat.Wechter@ars.usda.gov. available for control of bacterial pathogens on cucurbits.

Acidovorax avenae subsp. citrulli (Aac) is a phytopathogenic bacterium responsible for the cucurbit disease bacterial fruit blotch. This seed-borne pathogen can infect plants at any growth stage but is typically seen at the seedling stage or at the mature fruit stage (Hopkins, 1989). On seedlings, and especially the cotyledons, the initial symptoms are water-soaking easily visible on the lower surface of the cotyledons or leaves. The water-soaked area quickly becomes necrotic, often with chlorotic halos. On older leaves, the necrosis can often be seen on the leaf margins followed by disease development along major veins. The pathogen also can affect the stems and hypocotyls of the emerging seedling, causing a damping-off condition in which the plant quickly collapses and dies. Both watermelon and cantaloupe fruit infected with this pathogen initially exhibit small greasy-looking areas caused by watersoaking of the outer rind. These fruit lesions expand rapidly, leaving large areas of affected tissue. As the disease develops, the pathogen eventually invades the flesh of the fruit causing the fruit to crack. A white froth coming from these affected fruit is often seen in the field in the later stages of infection. The seed-borne nature of this disease is of particular concern to the cucurbit industry because it can spread rapidly across great distances through infected seeds (Ha et al., 2009; Hopkins, 1989; Wang et al., 2007).

Fourteen haplotypes of Aac, based on pulsed field gel electrophoresis DNA analysis, have been reported (Walcott et al., 2000). These haplotypes fall into at least two distinct groups, Group I and Group II strains. Group I strains have been recovered from a number of cucurbit crops, including muskmelons and watermelon, whereas Group II strains are predominantly associated with bacterial fruit blotch of watermelon (Walcott et al., 2004). The only chemical controls currently available are the copper-based fungicides, which have been shown to have only limited effectiveness against this pathogen. In addition, careful monitoring of plants in seed production areas is crucial. Transplant production houses are at high risk for rapid disease development and spread as a result of the close spacing and high humidity and temperatures. Seed testing is very important for seed producers. The use of seedling grow-out assays are the current standard for Aac, although in recent years, considerable research and development has been done for molecular and enzyme-based detection strategies (Ha et al., 2009; Wang et al., 2007).

Bacterial fruit blotch has been documented in many countries. The disease is relatively new to the United States with the first reported outbreak in a commercial watermelon field in Florida in 1989 (Hopkins, 1989; Somodi et al., 1991). Since that time, considerable work has been done by state and federal agencies as well as extension and industry personnel to stem these outbreaks. There have been several reports of outbreaks of bacterial fruit blotch in the United States (Isakeit et al., 1998; Latin and Hopkins, 1995; Schaad et al., 2003) Although many of these outbreaks are associated with watermelon, outbreaks in muskmelon in the United States also have been reported with the latest being in the muskmelon variety 'Athena' in 2001 (http://www. tifton.uga.edu/veg/Alerts/CANTELOPE.htm). Outbreaks of this pathogen in muskmelon in other parts of the world have resulted in devastating losses (O’Brien and Martin, 1999).

The use of copper products is only marginally successful in reducing Aac outbreaks in the greenhouse and field, and because they are the only chemical controls available, their widespread use raises the risk of generating copper-resistant isolates of the bacterium (Hopkins, 1995; Walcott et al., 2004). Seed health, in terms of starting with non-contaminated seed, is important because the carryover of diseased plants into the field can result in severe bacterial fruit blotch problems (Hopkins and Thompson, 2002b). Seed treatments of hot water, peroxyacetic acid, or hydrochloric acid have proven to greatly reduce the occurrence of the disease (Feng et al., 2009). With the limited chemical options for managing this disease, several groups of researchers have looked at finding resistance to Aac in available germplasm. The majority of these studies have focused on watermelon germplasm. Hopkins and Thompson (2002a) screened more than 1300 Citrullus spp. and Praecitrullus fistulosus 
accessions from the U.S. plant germplasm collection for resistance to a strain of Aac. In that study, five PIs were found with significantly more resistance than the susceptible control plants. Subsequent inheritance studies indicated that the resistance is attributed to multiple genes with a complex mode of inheritance (Hopkins and Levi, 2008). Although resistance to this disease is needed in all cucurbit crops, the focus over the past 25 years has been in watermelon. Only recently has a screen for resistance to Aac been done in muskmelon. Bahar et al. (2008) screened 15 commercial cultivars/breeding lines and 20 wild muskmelon lines for resistance to an isolate of Aac. Although a fairly small number of lines was screened, significant differences in the level of susceptibility to the disease were found. The objectives of this study were to evaluate the Aac response of 332 select U.S. Cucumis spp. PIs using a vacuum inoculation and re-evaluate the tolerant PIs in replicated experiments using spray inoculation.

\section{Materials and Methods}

Bacterial isolates. Bacterial isolates were obtained under a USDA, APHIS permit from Dr. Ron Walcott, University of Georgia, Athens, GA. A mixture of four bacterial isolates was used for each test. The isolates were collected from citron, pumpkin, muskmelon, and watermelon (Table 1). Each isolate was started from $-80^{\circ} \mathrm{C}$ glycerol freezer stocks for each experiment. Four isolates from four different hosts were used so as to avoid screening for resistance to only a single isolate of the pathogen. The isolates were streaked onto Difco ${ }^{\mathrm{TM}}$ nutrient agar (NA) medium (Becton, Dickinson and Company, Sparks, $\mathrm{MD})$ and grown for $24 \mathrm{~h}$ at $27^{\circ} \mathrm{C}$. Single colonies from these 24-h-old plates were again transferred to NA plates and grown for an additional $24 \mathrm{~h}$ for use in the described assays.

Plant material. Seeds of PIs were obtained from the USDA, ARS, North Central Regional Plant Introduction Station (NCRPIS) in Ames, IA. The accessions were chosen based on observations of possible Aac resistance by Dr. Charles Block, Plant Pathologist, USDA, ARS, NCRPIS. A total of 351 Cucumis spp. accessions were selected for testing for resistance to Aac. The majority, 311, of theses accessions were Cucumis melo and C. melo subspecies and varieties. The remaining PIs were comprised of $C$. africanus, C. anguria, C. asper, C. dipsaceus, C. ficifolius, C. heptadactylus, C. meeusei, C. myriocarpus, C. prophetarum, C. pustulatus, C. sagittatus, and C. subsericeus. In addition to the 351 PI accessions, the commercial susceptible cultivar of

Table 1. Acidovorax avenae subsp. citrulli isolates used for study.

\begin{tabular}{llcl}
\hline Isolates & Host & Group & Origin \\
\hline $206-40$ & Citron & I & Texas \\
$98-17$ & Pumpkin & I & Georgia \\
$200-6$ & Melon & I & Georgia \\
AAC00-1 & Watermelon & II & Georgia \\
\hline
\end{tabular}

C. melo Hale's Best Jumbo was used as a control for the tests.

Seed vacuum-infusion assay. The initial screening of the germplasm was performed using a seed vacuum-infusion assay described subsequently using 10 seeds of each PI and susceptible cultivar checks that were infused with the bacterium. An equal number of seed was infused with sterile $\mathrm{H}_{2} \mathrm{O}$ to monitor the effect of infusion on seed germination and for the presence of seed-borne inoculum. Twentyfour-h-old Aac cultures from NA plates from single-colony isolations described previously were flushed with sterile deionized (sdi) $\mathrm{H}_{2} \mathrm{O}$ with bacterial cells being removed with a bent glass rod. Each isolate was resuspended in sdi- $\mathrm{H}_{2} \mathrm{O}$ to an optical density of 1.0 at $600 \mathrm{~nm}$ $\left[\approx 4\right.$ to $5 \times 10^{8}$ colony-forming units $(\mathrm{cfu}) / \mathrm{mL}$ as determined by dilution plating] using a Biophotometer (Eppendorf, Westbury, NY) and then combined with the other three isolates in equal amounts. Ten seeds of each PI were placed in a $250-\mathrm{mL}$ side-arm flask with $15 \mathrm{~mL}$ of the inoculum (or sdi- $\mathrm{H}_{2} \mathrm{O}$ in controls); the flask then was sealed with a silicon stopper and fitted to a vacuum apparatus. A vacuum was applied for $30 \mathrm{~s}$ and then abruptly released, verifying seed infiltration by a stream of bubbles emerging from each seed. This was repeated three times, holding the vacuum for $5 \mathrm{~min}$ on the third infiltration. Seeds then were strained through a fine sieve and added to sterile $77 \mathrm{~mm} \times 77 \mathrm{~mm} \times 97-\mathrm{mm}$ Magenta GA-7 Plant Culture boxes (Magenta Corporation, Chicago, IL) containing pasteurized vermiculite; $30 \mathrm{~mL}$ of sdi- $\mathrm{H}_{2} \mathrm{O}$ was added and then the boxes were sealed with a sterile lid. The seeds were distributed in the vermiculite by vigorous shaking. In addition, 20 seeds (10 bacteria-treated and $10 \mathrm{sdi}-\mathrm{H}_{2} \mathrm{O}$-treated) of the susceptible muskmelon cultivar Hale's Best Jumbo was also included in each test as a susceptible control.

The seed-containing magenta boxes were placed in a lighted environmental chamber with a 12-h diurnal light cycle, a temperature of $30{ }^{\circ} \mathrm{C}$ day $/ 28{ }^{\circ} \mathrm{C}$ night, and a relative humidity of $80 \%$. After $48 \mathrm{~h}$ in the environmental chamber, lids were removed for the duration of the test. At $5 \mathrm{~d}$ post-inoculation, 20 $\mathrm{mL}$ sdi- $\mathrm{H}_{2} \mathrm{O}$ was added to each magenta box. Individual plants were rated at $10 \mathrm{~d}$ post-inoculation for germination, and germinated plants were rated for disease based on the following 1 to 9 scale: $1=$ no symptoms; $2=$ single, small necrotic lesions on less than $1 \%$ of the cotyledon; $3=$ small necrotic lesions on $1 \%$ to $10 \%$ of the cotyledon; $4=$ necrotic lesions on $11 \%$ to $20 \%$ of the cotyledon; $5=$ necrotic lesions with chlorosis on greater than $20 \%$ to $40 \%$ of the cotyledon; $6=$ necrotic lesions on $40 \%$ to $60 \%$ of the cotyledon; $7=$ necrotic lesions on $61 \%$ to $80 \%$ of cotyledon; $8=$ large spreading lesions, greater than $85 \%$ of cotyledon; and $9=$ dead plant. The seed infusion assay with 332 PIs was conducted two times. Data from each of the two seed vacuum experiments were used as a replication and a Kruskal-Wallis test was performed to determine if the median disease ratings differed among the PIs using the proc nparlway procedure of SAS (Version 8.0; SAS Institute, Cary, NC).

All PIs as well as the susceptible cultivar Hale's Best Jumbo were tested twice with the seed infusion assay. Although most of the individual plants tested for each PI had relatively similar scores, some PIs tested showed varying degrees of segregation for resistance within a PI. A number of those segregating populations that had individual plants that were rated as 1 (i.e., no symptoms) in both infusion assays. Nineteen of the 351 PI accessions tested had zero germination in either the inoculated or water-control treatment in both seed infusion assays and were not tested further. A third vacuum-infusion seed assay was performed with the best overall performers in the first two assays as well as those PIs that consistently had individuals scoring 1 in the first two assays regardless of the mean score for that PI. These segregating PIs were included in the third assay to determine if the low ratings were a result of an inoculum "escape" or were truly segregating for resistance. Based on the results of these three seed assays, a subset of PIs was selected for resistance testing in a standard spray inoculation test described subsequently.

Spray inoculation assay. As a result of the uniqueness of the vacuum-infusion seed inoculation method for this pathogen, we chose to also perform a spray inoculation test used in screening for Aac resistance in watermelon (Hopkins and Thompson, 2002a). The best performers in the seed infusion tests were tested in the spray test. The spray testing was used to validate the results in the first tests and support the validity for the use of vacuuminfusion as a standard screening method for resistance to Aac. In addition, we hypothesized that if different mechanisms were responsible for resistance at the seed stage versus a more mature plant, they may be observable between the two types of tests. Sixteen seeds of each select PI were sown in Metro-Mix 360 soil mix (The Scott's Co., Maryville, $\mathrm{OH}$ ) in $8 \mathrm{~cm} \times 8$ $\mathrm{cm} \times 9-\mathrm{cm}$ pots. Eight of the most uniform plants from each tested PI were selected and maintained in the greenhouse $\left(25\right.$ to $\left.28^{\circ} \mathrm{C}\right)$. The plants were arranged in eight blocks with a single plant of each PI in a block. The plants were grown to the second fully expanded leaf stage and inoculated with a $1 \times 10^{6} \mathrm{cfu} / \mathrm{mL}$ per isolate (determined by optical density measurements at a wavelength of $600 \mathrm{~nm}$ as well as dilution plating), four-isolate mixture. The plants were sprayed to runoff with the bacterial mixture or sdi- $\mathrm{H}_{2} \mathrm{O}$ using a Paasche $\mathrm{H}$-series airbrush (Paasche Airbrush Co., Chicago, IL) with a No. 3 spray head at 20 psi and then placed in a dew chamber with $90 \%$ to $100 \%$ humidity at $28{ }^{\circ} \mathrm{C}$ for $48 \mathrm{~h}$. Eight replicate of single plants from each tested PI were randomized within the growth chamber and maintained using the same conditions as for the seed vacuum-infusion assay. Individual plants within each PI were rated $10 \mathrm{~d}$ postinoculation using the following rating system of Hopkins and Thompson (2002a): $1=$ no symptoms; 2 = few small necrotic lesions on cotyledons; 3 = small, necrotic lesion on cotyledons, $20 \%$ or less necrotic cotyledon; 
Table 2. Response of seedlings of melon plant introductions (PIs) to bacterial fruit blotch caused by Acidovorax avenae subsp. citrulli. ${ }^{\text {. }}$

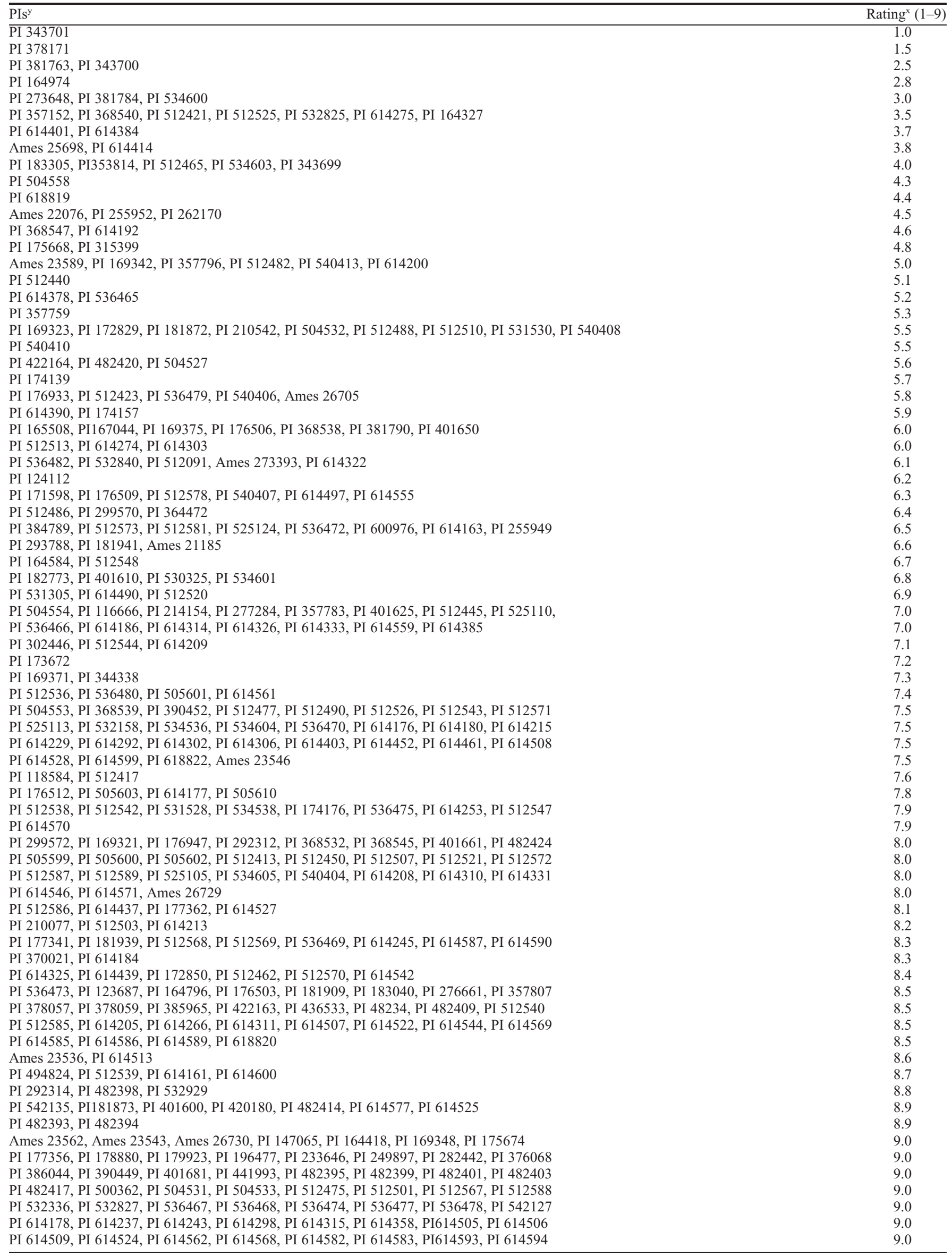


Table 2. (Continued) Response of seedlings of melon plant introductions (PIs) to bacterial fruit blotch caused by Acidovorax avenae subsp. citrulli. ${ }^{\mathrm{z}}$

\begin{tabular}{|c|c|}
\hline $\mathrm{PIs}^{\mathrm{y}}$ & Rating $^{\mathrm{x}}(1-9)$ \\
\hline PI 614596, PI 614601 & 9.0 \\
\hline Kruskal-Wallis test $\chi^{2}$ & 467.8 \\
\hline Degrees of freedom & 331.0 \\
\hline $\operatorname{Pr}>\chi^{2}$ & $<0.0001$ \\
\hline
\end{tabular}

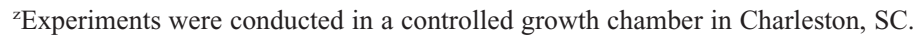

y Details of individual PIs can be obtained from GRIN (http://www.ars-grin.gov).

${ }^{x}$ Details of the 1 to 9 rating scale are provided in the text. The ratings provided here are a mean of two independent experiments.

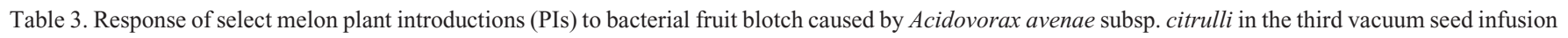
assay.

\begin{tabular}{|c|c|c|c|c|c|c|c|c|c|}
\hline $\mathrm{PI}^{\mathrm{z}}$ & $\begin{array}{c}\text { Average } \\
\text { rating }(1-9)^{\mathrm{y}}\end{array}$ & $\pm \mathrm{SE}^{\mathrm{x}}$ & Z-score ${ }^{w}$ & $\begin{array}{l}\text { Seedlings } \\
\text { rated } \\
2 \text { or less }^{v}\end{array}$ & $\mathrm{PI}^{\mathrm{z}}$ & $\begin{array}{c}\text { Average } \\
\text { rating }(1-9)^{\mathrm{y}}\end{array}$ & $\pm \mathrm{SE}^{\mathrm{x}}$ & Z-score ${ }^{w}$ & $\begin{array}{l}\text { Seedlings } \\
\text { rated } \\
2 \text { or less }\end{array}$ \\
\hline PI 175668 & 2.0 & 0.00 & -1.83 & 100 & PI 512421 & 6.2 & 0.18 & 0.25 & 0 \\
\hline PI 343701 & 2.3 & 1.15 & -1.66 & 50 & PI 174157 & 6.5 & 0.26 & 0.40 & 0 \\
\hline PI 422164 & 2.7 & 1.04 & -1.50 & 75 & PI 167044 & 6.7 & 0.31 & 0.48 & 0 \\
\hline PI 353814 & 2.8 & 0.56 & -1.46 & 20 & PI 614275 & 6.7 & 1.06 & 0.48 & 29 \\
\hline PI 343700 & 3.2 & 1.16 & -1.25 & 57 & Ames 26705 & 6.7 & 1.11 & 0.48 & 14 \\
\hline PI 512525 & 3.6 & 1.28 & -1.04 & 33 & PI 531303 & 6.8 & 0.43 & 0.52 & 0 \\
\hline PI 164974 & 3.7 & 1.00 & -1.00 & 57 & PI 512587 & 7.0 & 0.50 & 0.64 & 0 \\
\hline Ames 22076 & 4.0 & 0.71 & -0.84 & 30 & PI 531530 & 7.0 & 0.00 & 0.64 & 0 \\
\hline PI 512482 & 4.0 & 1.32 & -0.84 & 40 & Ames 21185 & 7.2 & 0.15 & 0.72 & 0 \\
\hline PI 614401 & 4.1 & 1.19 & -0.78 & 56 & PI 532629 & 7.2 & 0.34 & 0.74 & 0 \\
\hline PI 512581 & 4.2 & 0.79 & -0.74 & 17 & PI 181872 & 7.3 & 0.29 & 0.81 & 0 \\
\hline PI 534600 & 4.3 & 0.67 & -0.72 & 20 & Ames 25698 & 7.5 & 0.21 & 0.89 & 0 \\
\hline PI 183305 & 4.3 & 1.04 & -0.68 & 25 & PI 174139 & 7.5 & 0.32 & 0.89 & 0 \\
\hline PI 116666 & 4.4 & 1.37 & -0.64 & 50 & PI 614292 & 7.5 & 0.26 & 0.89 & 0 \\
\hline PI 614414 & 4.6 & 1.00 & -0.56 & 38 & PI 618819 & 7.6 & 0.22 & 0.94 & 0 \\
\hline PI 504558 & 4.7 & 2.02 & -0.51 & 25 & PI 614378 & 7.7 & 0.34 & 1.00 & 0 \\
\hline PI 378171 & 4.7 & 1.15 & -0.49 & 38 & PI 381784 & 7.8 & 0.24 & 1.01 & 0 \\
\hline PI 169323 & 5.0 & 1.12 & -0.35 & 33 & PI 273648 & 8.0 & 0.00 & 1.14 & 0 \\
\hline PI 368540 & 5.4 & 1.10 & -0.13 & 25 & Ames 27393 & 8.0 & 0.00 & 1.14 & 0 \\
\hline PI 512510 & 5.6 & 0.55 & -0.05 & 0 & PI 512465 & 8.0 & 0.29 & 1.14 & 0 \\
\hline PI 614384 & 5.6 & 1.02 & -0.04 & 22 & PI 302446 & 8.2 & 0.15 & 1.22 & 0 \\
\hline Ames 23589 & 5.7 & 1.41 & -0.02 & 14 & PI 614555 & 8.3 & 0.15 & 1.26 & 0 \\
\hline PI 614200 & 5.7 & 0.82 & -0.02 & 0 & PI 169375 & 8.5 & 0.18 & 1.38 & 0 \\
\hline PI 381763 & 5.7 & 0.34 & 0.01 & 0 & PI 614490 & 8.6 & 0.28 & 1.42 & 0 \\
\hline PI 614192 & 5.7 & 0.91 & 0.01 & 25 & PI 118584 & 8.8 & 0.15 & 1.51 & 0 \\
\hline PI 169321 & 6.1 & 0.24 & 0.22 & 0 & & & & & \\
\hline
\end{tabular}

${ }^{\mathrm{z}}$ Details of the various melon PIs can be obtained from http://www.ars-grin.gov.

${ }^{\mathrm{y}}$ Mean ratings are based on ratings taken $10 \mathrm{~d}$ after inoculation on 10 plants.

${ }^{\mathrm{x}_{S E}}$ based on 10 single plant ratings taken for each PI.

${ }^{w} Z$-scores are based on the SD for the entire data set and the individual PI means.

vercentage of seedlings within each PI that was rated 2 or less on the 1 to 9 scale.

$4=$ small, necrotic lesions on greater than $20 \%$ of cotyledon; $5=$ necrotic lesions with chlorosis on cotyledons, $20 \%$ to $50 \%$ necrotic cotyledon; $6=$ necrotic lesions on $20 \%$ to $50 \%$ of cotyledon with restricted lesion on true leaf; $7=$ large spreading lesions, greater than $50 \%$ of cotyledon necrotic with restricted lesions on true leaves; $8=$ large spreading lesions, greater than $50 \%$ of cotyledon necrotic and chlorosis on true leaves; and $9=$ greater than $90 \%$ of the cotyledon necrotic with large spreading lesions on the true leaves or a dead plant. BFB rating from each individual plant was considered as a replication. Data on bacterial fruit blotch development on these seedlings from the two spray inoculation tests were analyzed using non-parametric methods. The average ranks of the PIs were compared using the KruskalWallis multiple comparisons MINITAB Macro Dunn's test that can be obtained from the following web site: http://www.mintab.com/ support/documentation/answers/KrusMC.PDF. The reaction of individual PIs to BFB evaluated in the spray tests was considered significantly different from each other if the $P$ value for the comparison was $\leq 0.05$.

\section{Results and Discussion}

Nineteen of the 351 PIs did not germinate in either of the initial vacuum-infusion screenings. Of the remaining 332 PIs, we found that the majority (59\%) exhibited high susceptibility (all plants were rated a 7 or greater) to the bacterial mixture in both tests (Table 2). Significant $(P<0.0001)$ differences in the development of bacterial fruit blotch was observed among the 332 PIs after the seed infusion assay according to the Kruskal-Wallis test. Twenty-four PIs had mean ratings less than 4 in the first two seed infusion assays (Table 2). However, as has been observed before (Bahar et al., 2008; Hopkins and Thompson, 2002a), plants within these PIs varied widely in their reaction to BFB. Fifty-one accessions either had vastly different ratings to the pathogen in the two seed infusion tests or appeared to have individual plants within a population with ratings of 1 in both tests (data not shown) and these were re-tested a third time in the seed vacuuminfusion test (Table 3). Sixteen PIs that appeared to segregate for resistance to Aac, had plants that scored a 1 in each of the three tests, or had a uniformly low disease rating for the individual plants in this final vacuum-infusion test were selected for evaluation in standard spray inoculation tests (Tables 4 and 5). The spray inoculation tests also included the cultivar Hale's Best Jumbo, PI 147065, PI 536473, PI 614525, and PI 123687 as susceptible checks.

The seed vacuum-infusion assay allowed for a relatively rapid screening of the 332 selected PIs. The inoculation levels were fairly stringent using a four-isolate mixture with each isolate having a concentration of at least $4 \times 10^{8}$ $\mathrm{cfu} / \mathrm{mL}$. We chose the high inoculum concentration to avoid "escapes" in the assay as well as to determine which accessions had the greatest level of resistance. In addition, the use of isolates from different cucurbits as well as from the two major haplotypes groups (Table 1) decreased the possibility of selecting resistance that is specific to a single isolate of the bacterium. An example of this problem occurred when Sowell and Schaad (1979) used a single Aac isolate to identify two watermelon PIs as resistant to the pathogen that in a later study by Hopkins et al. (1993) using a different isolate of Aac, these same PIs were found to be susceptible. 
Table 4. Bacterial fruit blotch development on seedlings of select melon (Cucumis spp.) plant introductions (PIs) spray-inoculated with a mixture of four isolates of Acidovorax avenae subsp. citrulli in a controlled growth chamber (Spray test 1).

\begin{tabular}{|c|c|c|c|c|c|c|}
\hline \multirow{2}{*}{$\frac{\text { PI }}{\text { PI } 353814}$} & \multirow{2}{*}{$\begin{array}{l}\text { Cucumis } \\
\text { species }^{z}\end{array}$} & \multirow{2}{*}{$\begin{array}{c}\text { Country }^{\mathrm{y}} \\
\text { Israel }\end{array}$} & \multicolumn{2}{|c|}{ Avg rank ${ }^{\mathrm{w}}$} & \multirow{2}{*}{$\begin{array}{c}\begin{array}{c}\text { Avg rating } \\
(1-9)\end{array} \\
1.0\end{array}$} & \multirow{2}{*}{$\begin{array}{c}\begin{array}{c}\text { Seedlings } \\
\text { rated }^{\mathrm{v}}\end{array} \\
\text { less than } 2 \\
100\end{array}$} \\
\hline & & & 10.0 & $\mathrm{a}$ & & \\
\hline PI 378171 & melo & Israel & 21.0 & $\mathrm{a}$ & 1.4 & 86 \\
\hline PI 504558 & ficifolius & India & 20.8 & $\mathrm{a}$ & 1.4 & 100 \\
\hline PI 536473 & melo & Maldives & 26.0 & $a b$ & 1.6 & 88 \\
\hline PI 614401 & melo & India & 29.1 & $a b$ & 1.8 & 100 \\
\hline PI 614414 & melo & India & 46.8 & $a b c$ & 2.5 & 60 \\
\hline Ames 22076 & anguria & Zambia & 50.8 & $a b c$ & 2.6 & 50 \\
\hline PI 614275 & melo & India & 57.5 & $a b c$ & 3.0 & 50 \\
\hline PI 422164 & melo & Czech. & 64.5 & abcd & 3.2 & 0 \\
\hline PI 343700 & pustulatus & Nigeria & 67.6 & bcd & 3.6 & 50 \\
\hline PI 164974 & melo & Turkey & 72.1 & cde & 3.7 & 29 \\
\hline PI 512482 & melo & Spain & 76.5 & cdef & 3.9 & 0 \\
\hline Ames 26705 & melo & United States & 93.6 & def & 4.8 & 0 \\
\hline PI 512525 & melo & Spain & 99.2 & defg & 5.0 & 0 \\
\hline PI 512581 & melo & Spain & 102.6 & defg & 5.3 & 0 \\
\hline Ames 23589 & anguria & South Africa & 115.8 & efg & 6.0 & 0 \\
\hline PI 147065 & anguria & Brazil & 114.9 & efg & 6.0 & 0 \\
\hline PI 123687 & melo & India & 122.1 & fg & 6.3 & 0 \\
\hline PI 343701 & pustulatus & Nigeria & 137.6 & $\mathrm{~g}$ & 7.1 & 0 \\
\hline PI 614525 & melo & India & 140.5 & $\mathrm{~g}$ & 7.3 & 0 \\
\hline HBJ & melo & United States & 124.5 & $\mathrm{~g}$ & 6.4 & 0 \\
\hline
\end{tabular}

${ }^{2}$ Details of Cucumis species listed can be obtained from http://www.ars-grin.gov.

${ }^{y}$ Country column indicates where the PI was originally collected.

${ }^{\mathrm{x}}$ Average ratings are based on ratings taken $10 \mathrm{~d}$ after inoculation on eight single plant replications.

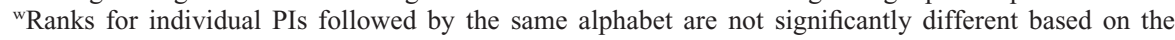
Kruskal-Wallis multiple comparison Dunn test $(\alpha=0.05)$.

vercentage of seedlings within each PI that was rated 2 or less on the 1 to 9 scale.

HBJ = Melon cultivar Hale's Best Jumbo.

Table 5. Bacterial fruit blotch development on seedlings of select melon (Cucumis spp.) plant introductions (PIs) spray-inoculated with a mixture of four isolates of Acidovorax avenae subsp. citrulli in a controlled growth chamber (Spray test 2).

\begin{tabular}{|c|c|c|c|c|c|c|}
\hline \multirow{2}{*}{$\frac{\text { PI }}{\text { PI } 504558}$} & \multirow{2}{*}{$\begin{array}{c}\begin{array}{c}\text { Cucumis } \\
\text { species }^{\mathrm{z}}\end{array} \\
\text { ficifolius }^{\text {infli }}\end{array}$} & \multirow{2}{*}{$\begin{array}{l}\text { Country }^{\mathrm{y}} \\
\text { India }\end{array}$} & \multicolumn{2}{|c|}{ Avg rank ${ }^{\mathrm{w}}$} & \multirow{2}{*}{$\begin{array}{c}\begin{array}{c}\text { Avg rating } \\
(1-9)^{\mathrm{x}}\end{array} \\
1.5\end{array}$} & \multirow[t]{2}{*}{$\begin{array}{c}\begin{array}{c}\text { Seedlings } \\
\text { rated }\end{array} \\
2 \text { or less } \\
100\end{array}$} \\
\hline & & & 27 & $\mathrm{a}$ & & \\
\hline PI 378171 & melo & Israel & 27 & $\mathrm{a}$ & 1.5 & 100 \\
\hline PI 536473 & melo & Maldives & 31 & $\mathrm{a}$ & 1.6 & 100 \\
\hline PI 353814 & melo & Israel & 31 & $\mathrm{a}$ & 1.6 & 88 \\
\hline PI 614401 & melo & India & 31 & $\mathrm{a}$ & 1.6 & 100 \\
\hline Ames 22076 & anguria & Zambia & 47 & $a b$ & 2.1 & 75 \\
\hline PI 614275 & melo & India & 61 & $a b$ & 2.6 & 38 \\
\hline PI 614414 & melo & India & 67 & $a b$ & 2.8 & 25 \\
\hline PI 164974 & melo & Turkey & 61 & $a b c$ & 2.9 & 63 \\
\hline PI 422164 & melo & Czech. & 69 & $a b c$ & 2.9 & 25 \\
\hline PI 343700 & pustulatus & Nigeria & 63 & $a b c$ & 2.9 & 38 \\
\hline Ames 26705 & melo & United States & 86 & bcd & 3.6 & 0 \\
\hline PI 512482 & melo & Spain & 93 & cde & 4.0 & 0 \\
\hline PI 512525 & melo & Spain & 117 & def & 5.8 & 0 \\
\hline Ames 23589 & anguria & South Africa & 125 & def & 6.3 & 0 \\
\hline PI 512581 & melo & Spain & 129 & ef & 6.5 & 0 \\
\hline PI 123687 & melo & India & 143 & $\mathrm{f}$ & 7.4 & 0 \\
\hline PI 343701 & pustulatus & Nigeria & 149 & $\mathrm{f}$ & 7.6 & 0 \\
\hline PI 147065 & anguria & Brazil & 152 & $\mathrm{f}$ & 7.9 & 0 \\
\hline PI 614525 & melo & India & 158 & $\mathrm{f}$ & 8.3 & 0 \\
\hline HBJ & melo & United States & 154 & $\mathrm{f}$ & 8.0 & 0 \\
\hline
\end{tabular}

${ }^{2}$ Details of Cucumis species listed can be obtained from http://www.ars-grin.gov.

${ }^{y}$ Country column indicates where the PI was originally collected.

${ }^{x}$ Average ratings are based on ratings taken $10 \mathrm{~d}$ after inoculation on eight single plant replications.

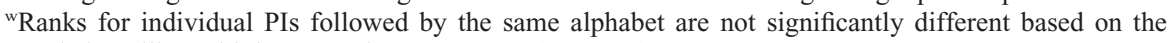
Kruskal-Wallis multiple comparison Dunn test $(\alpha=0.05)$

"Percentage of seedlings within each PI that was rated 2 or less on the 1 to 9 scale.

HBJ = Melon cultivar Hale's Best Jumbo.

An equal number of seeds of each PI also were tested using water in place of the bacterial cocktail. This was performed to verify that the PIs were free of Aac or other possible seed-borne pathogens as received from the NCRPIS. In fact, plants of 35
Because of the uniqueness of the seed vacuum-infusion assay, we chose to use the more standard (Bahar et al., 2008; Hopkins and Thomson, 2002a) spray inoculation test as a validation test of the 16 selected accessions from the three seed infusion tests. In the two spray tests, seedlings of PI 353814, PI 381171, PI 504558, PI 536573, and PI 614401 had significantly $(P=0.05)$ lower ratings for BFB compared with the susceptible muskmelon cultivar Hale's Best Jumbo. Of these five PIs, seedlings of PI 504558 and PI 614401 were all rated less than 2 in both spray tests (Tables 4 and 5). The other three PIs had 88\% to $100 \%$ of the plants rated less than 2 in the two tests. These five PIs may be useful as potential sources of resistance to BFB for use in breeding programs. All five of these PIs were collected in Asia, two in Israel, two in India, and one from Maldives, located next to the Indian subcontinent. With more than 3000 Cucumis sp. accessions in the NCRPIS collection, and with several hundred of those having origins in Israel and India, PIs collected from these regions may possess more potential sources of resistance to this important disease.

It is interesting to note that PI 343701 , although performing quite well in all three vacuum seed infusion assays, appears to be one of the most susceptible PIs tested in the two spray inoculation tests. Similar results have been seen in other plant/pathogen systems such as downy mildew of brassica (Coelho and Monteiro, 2003; Wang et al., 2001) and powdery mildew of cucurbits (Davis et al., 2007; McCreight, 2003) in which it appears that either different genes or other mechanisms are involved in resistance at the cotyledon stage versus the true leaf stage. In our vacuum seed infusion tests, the ratings are taken on the cotyledons before development of the true leaves, whereas in the spray inoculation tests the plants are inoculated at the second fully expanded leaf stage and then by the time the ratings are taken several more leaves are often present. It is possible that we are seeing a similar phenomenon in this Cucumis study with the fruit blotch pathogen as has been observed in other studies evaluating resistance to diseases on cucurbits (Davis et al., 2007; McCreight, 2003).

Although a small number of studies have been performed to look for resistance to Aac in watermelon, only a single, small-scale study had been performed in muskmelon (Bahar et al., 2008). This is the first reported evaluation of an extensive and diverse germplasm collection for resistance to the bacterial fruit blotch pathogen and the first report of a highly resistant germplasm.

\section{Literature Cited}

Bahar, O., G. Kritzman, and S. Burdman. 2008 Bacterial fruit blotch of melon: Screens for disease tolerance and role of seed transmission in pathogenicity. Eur. J. Plant Pathol. 123:71-83.

Coelho, P.S. and A.A. Monteiro. 2003. Expression of resistance to downy mildew at cotyledon and adult plant stages in Brassica oleracea $\mathrm{L}$. Euphytica 133:279-284. 
Davis, A.R., A. Levi, A. Tetteh, T. Wehner, V. Russo, and M. Pitrat. 2007. Evaluation of watermelon and related species for resistance to race $1 \mathrm{~W}$ powdery mildew. J. Amer. Hort. Sci. 132:790-795.

Feng, J., J. Li, P. Randhawa, M. Bonde, and N.W. Schaad. 2009. Evaluation of seed treatments for the eradication of Acidovorax avenae subsp. citrulli from melon and watermelon seeds. Can. J. Plant Pathol. 31:180-185.

Ha, Y., A. Fessehaie, K.S. Ling, W.P. Wechter, A.P. Keinath, and R.R. Walcott. 2009. Simultaneous detection of Acidovorax avenae subsp. citrulli and Didymella bryoniae in cucurbit seedlots using magnetic capture hybridization and real-time polymerase chain reaction. Phytopathology 99:666-678.

Hopkins, D.L. 1989. Bacterial fruit blotch of watermelon: A new disease in the eastern USA, p. 74-75. In: Thomas, C.E. (ed.). Cucurbitaceae 1989. Proc. Evaluation and enhancement of Cucurbit germplasm. U.S. Vegetable Laboratory, Charleston, SC.

Hopkins, D.L. 1995. Copper-containing fungicides reduce the spread of bacterial fruit blotch of watermelon in the greenhouse. Phytopathology 85:510.

Hopkins, D.L. and A. Levi. 2008. Progress in the development of Crimson sweet-type watermelon breeding lines with resistance to Acidovorax avenae subsp. citrulli. In: Pitrat, M. (ed.). Cucurbitaceae 2008. Proc. IXth EUCARPIA meeting on genetics and breeding of Cucurbitaceae. Il'institut National de la, Recherche Agronomique, Avignon, France.
Hopkins, D.L. and C.M. Thompson. 2002a. Evaluation of Citrullus sp. germplasm for resistance to Acidovorax avenae subsp. citrulli. Plant Dis. 86:61-64.

Hopkins, D.L. and C.M. Thompson. 2002b. Seed transmission of Acidovorax avenae subsp. citrulli in cucurbits. HortScience 37:924-926.

Hopkins, D.L., C.M. Thompson, and G.W. Elmstrom. 1993. Resistance of watermelon seedlings and fruit to the fruit blotch bacterium. HortScience 28:122-123.

Isakeit, T., M.C. Black, and J.B. Jones. 1998. Natural infection of citronmelon with Acidovorax avenae subsp. citrulli. Plant Dis. 82:351.

Latin, R.X. and D.L. Hopkins. 1995. Bacterial fruit blotch of watermelon: The hypothetical exam question becomes reality. Plant Dis. 79:761-765.

McCreight, J.D. 2003. Genes for resistance to powdery mildew races 1 and 2 US in melon PI 313970. HortScience 38:591-594.

O’Brien, R.G. and H.L. Martin. 1999. Bacterial fruit blotch of melons caused by strains of Acidovorax avenae subsp. citrulli. Aust. J. Exp. Agr. 39:479-485.

Schaad, N.W., E. Postnikova, and P.S. Randhawa. 2003. Emergence of Acidovorax avenae subsp. citrulli as a crop-threatening disease of watermelon and melon, p. 573-581. In: Iacobellis, N.S., A. Coller, S.W. Hutcheson, J.W. Mansfield, C.E. Morris, J. Murillo, N.W. Schaad, D.E. Stead, G. Surico and M.S. Ullrich (eds.). Pseudomonas syringae and related pathogens. Kluwer, Dordrecht, The Netherlands.

Somodi, G.C., J.B. Jones, D.L. Hopkins, R.E. Stall, T.A. Kucharek, N.C. Hodge, and J.C. Watter- son. 1991. Occurrence of a bacterial watermelon fruit blotch in Florida. Plant Dis. 75: 1053-1056.

Sowell, G.C. and N.W. Schaad. 1979. Pseudomonas pseudoalcaligenes subsp. citrulli on watermelon: Seed transmission and resistance of plant introductions. Plant Dis. Rep. 63:437-441.

USDA, NASS. 2009. Watermelons, vegetables, potatoes, and melons harvested for sale: 2007 and 2002, 2007 Census of Agriculture-State data, National Agricultural Statistics Service, USDA.

Walcott, R.R., A. Fessehaie, and A.C. Castro. 2004. Differences in pathogenicity between two genetically distinct groups of Acidovorax avenae subsp. citrulli on cucurbit hosts. J. Phytopathol. 152:277-285.

Walcott, R.R., D.B. Langston, Jr., F.H. Sanders, Jr., and R.D. Gitaitis. 2000. Investigating intraspecific variation of Acidovorax avenae subsp. citrulli using DNA fingerprinting and whole cell fatty acid analysis. Phytopathology 90:191-196.

Wang, M., M.W. Farnham, and C.E. Thomas. 2001. Inheritance of true leaf stage downy mildew resistance in broccoli. J. Amer. Soc. Hort. Sci. 126:727-729.

Wang, X., L. Zhang, F.-S. Xu, L.-H. Zhao, and G.-L. Xie. 2007. Immuno-capture PCR method for detecting Acidovorax avenae subsp. citrulli from watermelon. Chin. J. Agr. Biotechnol. 4:173-179.

Zitter, T.A., D.L. Hopkins,, and C.E. Thomas (eds.). 1996. Compendium of cucurbit diseases. The American Phytopathological Society, St Paul, MN. 